\title{
Enzyme Activity Influenced by Modified Atmospheric Packaging on Onion Seeds (Allium cepa L.) cv. Arka Kalyan
}

\author{
Koteshi Lamani*, V. K. Deshpande, T. R. Shashidhar and N. K. Biradar Patil \\ Department of Seed Science and Technology, University of Agricultural Sciences, \\ Dharwad-580005, Karnataka (India) \\ *Corresponding author
}

Ke y w o r d s
Cold storage,
Enzyme, Onion,
Seed vigor, Vacuum
Article Info
Accepted:
20 October 2020
Available Online:
10 November 2020

\section{A B S T R A C T}

\section{Introduction}

Onion (Allium cepa L.) is a member of family Amaryllidaceae. It is one of the major bulb crops of the world and important commercial vegetable grown all over the world and occupies a premier position amongst the vegetables due to its high preference in food, remunerative price and regular demand in the market. India ranks first in total area under 
onion cultivation (12.25 lakh hectares) with second largest producer (209.91 lakh million tonnes) in the world next to China, but the productivity of onion in India is very low i.e., 17.13 tonnes per ha as compared to China and other countries like, Egypt, Netherland and Iran etc.,. Hence, there is a need to enhance the productivity and production. Most of the onion produced in India comes from Maharashtra (28.62 \%) state followed by Karnataka (15.94 \%), Madhya Pradesh, Bihar, Gujarat Andhra Pradesh and Uttar Pradesh. Karnataka alone occupies around 195.29 thousand ha area with 2,767.98 thousand million tonnes of production and the average productivity is 16.13 tonnes per ha which is again very low compared to national productivity average.

Onion is the only vegetable in which India figures predominantly in the world for production and export. The average productivity of onion is quite low (12.82 t/ha) in India. Among the vegetables, onion seeds are classified as very poor storer, because of low availability of quality seed for planting is a major problem faced by the farmers. After the seeds are harvested, controlling seed deterioration becomes more difficult because, the seeds are much more sensitive to conditions and environments that cause loss of quality.

Modified atmosphere storage of seeds is a suitable alternative to the use of chemical fumigants and contact insecticides that are known to leave carcinogenic residues in the treated products (Bailey and Banks, 1980). Disinfestations of stored seeds using modified atmospheric storage (MA) involves the alteration of the natural storage gases such as carbon dioxide $\left(\mathrm{CO}_{2}\right)$, oxygen $\left(\mathrm{O}_{2}\right)$ and nitrogen $\left(\mathrm{N}_{2}\right)$, to render the atmosphere in the stores lethal to pests. The MA includes neither alteration of the storage atmosphere by addition of toxic gases such as phosphate methyl bromide or regulation or alteration of the atmospheric water content. The MA may be achieved in several ways: by adding gaseous or solid $\mathrm{CO}_{2}$, by adding a gas of low $\mathrm{O}_{2}$ content (e.g., pure $\mathrm{N}_{2}$ or output from a hydrocarbon burner) or by allowing metabolic processes within an airtight storage to remove $\mathrm{O}_{2}$, usually with associated release of $\mathrm{CO}_{2}$. Such atmospheres are referred to as 'high$\mathrm{CO}_{2}$ ', 'low- $\mathrm{O}_{2}$ ' and 'hermetic storage' atmospheres, respectively. They are collectively known as 'modified atmospheres' (Banks and Fields, 1995). The effectiveness of modified atmosphere for controlling various stored product pests depends on the temperature and moisture content of the seeds, species and life storage of pests, gaseous composition and uniformity of gas distribution and exposure time of the MA treatment (Lukasiewicz et al., 1999). If the seeds are not sold in time, then it has to be carried to the next season which definitely affects the seed viability.

\section{Materials and Methods}

The laboratory experiments were conducted in the laboratory of Seed unit, University of Agricultural Sciences, Dharwad during 20162017 and the packaging of the onion seeds were carried out in the Department of Processing and Food Engineering, College of Agricultural Engineering, UAS, Raichur using the Modified Atmosphere Packaging (MAP) Unit and for cold storage seeds of particular treatment was kept in cold storage unit, department of Environmental Science, University of Agricultural Sciences, Dharwad, Karnataka

\section{Experimental details}

The storage experiment consisted of totally 15 treatment combinations and details of the treatments are furnished below, out of them 12 treatments were comprised of seed storage under gaseous combinations of carbon dioxide, oxygen and nitrogen and 1 treatment 
in cold storage. Rest of two treatments were used to compare gaseous combinations with seeds stored cloth bag and atmospheric air in polythene bag.

\section{Method of modified atmosphere packaging}

Polythene bags of 700 gauge measuring 20 $\mathrm{cm}$ (length) and $14 \mathrm{~cm}$ (breadth) were used for packing purpose. In these bags, 200 grams of onion seeds were packed along with the gases like carbon dioxide, nitrogen and oxygen in different concentrations according to the treatments. Firstly, the valves of the gas cylinders were opened and they were released at a pressure of $7 \mathrm{~kg}$ per $\mathrm{cm}^{2}$ and the different combinations of carbon dioxide, nitrogen and oxygen were mixed in the mixing chamber. According to the treatments given, the gas flow rate was controlled in the buffer tank which was directly connected to the packaging unit. 200 grams of onion seeds were packed using the packaging unit by evacuating the air and then flushed with the gases of required combinations and automatically sealed.

Composition of the gas i.e., $\mathrm{O}_{2}$ and $\mathrm{CO}_{2}$ gas concentrations inside the package was checked by Check mate gas analyser with the help of septum, which prevents leakage of (head space) gas from polyethylene bag while taking readings of change in gas concentration.

\section{Procedure to use MAP instrument}

The cylinders containing Carbon dioxide $\left(\mathrm{CO}_{2}\right)$, Oxygen $\left(\mathrm{O}_{2}\right)$ and Nitrogen $\left(\mathrm{N}_{2}\right)$ gas as in Plate 1 were checked for pressure and the pressure of the gases was adjusted by following the steps detailed below.

The top dial in the mixing chamber was adjusted to the required $\mathrm{CO}_{2}$ gas concentration and the value of $\mathrm{X}$ (mentioned below the upper dial) was noted then adjusted the bottom dial by calculating the value of $\mathrm{N}_{2} / \mathrm{X}$ (Plate 10 ), where $N_{2}$ is nitrogen concentration and $X$ is the value or number below the upper dial.

The desired gas concentrations were checked by using check mate gas analyzer (Plate 11). Through the gas sampling port the gases were allowed to pass through needle and the obtained gas concentration from the gas mixing chamber was checked and recorded.

If the required gas concentration was not achieved then dialer was fine tuned to get the exact gas concentration. The sampling port was closed and the gas collected in the buffer tank was evacuated.

Buffer tank (Plate 12) needed to be evacuated to achieve the required gas concentration. The gas was supplied through tube to the modified atmosphere packaging unit for packing of seeds.

In Packaging Unit (Plate 13) the heat level of sealing was adjusted to 2.0 to 2.5 to achieve proper sealing. The packaging material (polyethylene, 700 gauges) was kept in the packaging unit in which the vacuum was created by evacuating the air present in the packaging material and then filled the required gas concentration from buffer tank and sealed (Plate 14 and 15).

\section{Results and Discussion}

The results of dehydrogenase activity, $\alpha$ Amylase enzyme activity, Catalase enzyme activity and Superoxide dismutase (SOD) enzyme activity as influenced by modified atmospheric storage conditions and its effect during storage are presented in Table 1, 2, 3 and 4.

With an advancement of storage period, the mean enzyme activity declined rapidly, 
irrespective of modified atmospheric storage conditions. Different enzyme activity differed significantly due to modified atmospheric storage conditions in all the 12 months of storage irrespective of the modified atmospheric conditions. The seeds stored in Cold storage $\left(\mathrm{T}_{15}\right)$ recorded maximum dehydrogenase activity of (0.280), amylase enzyme activity of (1.28), catalase enzyme activity of (0.246), superoxide dismutase enzyme activity of (0.900) after twelve months of storage period followed by $\mathrm{T}_{1}: 80$ $\% \mathrm{CO}_{2}: 05 \% \mathrm{O}_{2}: 15 \% \mathrm{~N}_{2}$ and seeds stored in vacuum $\left(\mathrm{T}_{13}\right)$. The lowest dehydrogenase activity of (0.190), was noticed in seed stored in cloth bag $\left(\mathrm{T}_{14}\right)$ followed by the second the lowest dehydrogenase activity recorded (0.220), $\alpha$-amylase enzyme activity of (1.80), catalase enzyme activity of (0.156), superoxide dismutase enzyme activity recorded (0.730) in seeds stored in polythene bag with air $\left(\mathrm{T}_{12}\right)$ after twelve months of storage.

The present study indicated that seed qualitative characters and biochemical parameters like amylase activity, dehydrogenase activity, catalase, and superoxide dismutase (SOD) varied significantly due to modified atmospheric storage condition under ambient, cold storage and vacuum storage as individual treatments in all the months of storage period. As the storage period advanced, all the seed quality attributes were found to be decreased. Conversely, moisture content, EC values and seed infection increased significantly irrespective of modified atmospheric storage conditions. The seeds stored in ambient condition $\left(\mathrm{T}_{14}\right)$ recorded lower OD value with respect to dehydrogenase and amylase activity (0.190 and $1.80 \mathrm{u} . \mathrm{mol} / \mathrm{min} / \mathrm{g}$ ) compared to cold storage $\left(\mathrm{T}_{15}\right) \quad(0.280$ and 1.28 u.mol/min/g) which was followed by $\mathrm{T}_{1}-(80$ $\left.\% \mathrm{CO}_{2}: 05 \% \mathrm{O}_{2}: 15 \% \mathrm{~N}_{2}\right)(0.277$ and 1.28 u.mol/min $/ \mathrm{g})$ and $\mathrm{T}_{13^{-}}$vacuum (0.272 and 1.27 u.mol$/ \mathrm{min} / \mathrm{g}$ ). Higher values in the seeds stored in cold storage might be due to highest activity of these enzymes that indicate pivotal role played by these enzymes in breaking down the macromolecules of seed to provide soluble precursor for the synthesis of protein and carbohydrates accumulation (Rauf, 1980). Further higher germination and vigour with increase ageing might be due to higher enzyme activity.

In general, ageing is manifested by the decrease of metabolic activity and an increase of catabolic processes (Gorecki et al., 1996). In particular, an oxidative stress might be reduced in lower oxygen storage atmospheres (Justice and Bass, 1978; Wilson McDonald, 1986; Benson, 1990). It should be noted that seed deterioration during storage could result in marked changes in the content and activity of enzymes capable for degrading the stored reserves (Priestley, 1986; Smith and Berjak, 1995; Walters, 1998). In the present investigation, it was observed that the dehydrogenase activity in the seeds was maximum and hence, better maintenance of seed quality in modified atmospheric storage condition has been observed compared to control. Another reason for seed ageing may be the accumulation of deleterious effect on membranes due to oxidative damages to fatty acids and proteins denaturation as a result of Millard reactions (Narayana Murthy and Sun, 2000). The advantage of higher seed reserve utilization efficiency in seeds stored in vacuum, provide energy for a faster growing rate of the seedlings. In the present study also, maximum speed of germination (17.30 and 16.91) was noticed in the treatment $\mathrm{T}_{1}(80 \%$ $\mathrm{CO}_{2}+5 \% \mathrm{O}_{2}+15 \% \mathrm{~N}_{2}$ ) and $\mathrm{T}_{14}$ i.e., seeds stored in vacuum package respectively. The similar results were also reported by Rathi et al., (2000), Bera et al., (2004) and Bera et al., (2008).

SOD and CAT activities in onion seeds were observed to decrease with ageing in the present study. These results support the 
hypothesis of Bailly et al., (1996) that a decrease in antioxidant enzymes is linked to an increased lipid peroxidation and accelerated ageing. Subsequently, Bailly et al., (2000, 2002) proposed a positive relationship between antioxidant enzyme capacity and the vigour of the seed. Consequently, our results support the hypothesis of inactivation of free radical scavenging enzymes (i.e., SOD and CAT) during ageing and showed a direct relationship with the germination efficiency of ageing onion seeds. Moreover, our results provide convincing evidence that inactivation of these enzymes strongly increases below the $60 \%$ viability level in onion seeds. During storage, free radicals may be formed in the presence of even traces of oxygen. Initially, unsaturated fatty acid moieties get decomposed to form fatty acid hydroperoxide followed by hemolytic breakdown into alkoxyl radicals (Hopin et al., 1996). In the absence of active enzymes scavenging free radicals, degradation products of thermolabile lipid peroxidation accumulate in the ageing seeds, finally resulting in complete loss of seed viability (Rao et al., 2006).

\section{Details of the treatments are:}

\begin{tabular}{|c|l|}
\hline Treatments & \multicolumn{1}{|c|}{$\begin{array}{c}\text { Seed storage in different concentrations of gas } \\
\text { combinations }\end{array}$} \\
\hline $\mathbf{T}_{\mathbf{1}}$ & $80 \% \mathrm{CO}_{2}: 05 \% \mathrm{O}_{2}: 15 \% \mathrm{~N}_{2}$ \\
\hline $\mathbf{T}_{\mathbf{2}}$ & $70 \% \mathrm{CO}_{2}: 05 \% \mathrm{O}_{2}: 25 \% \mathrm{~N}_{2}$ \\
\hline $\mathbf{T}_{\mathbf{3}}$ & $60 \% \mathrm{CO}_{2}: 05 \% \mathrm{O}_{2}: 35 \% \mathrm{~N}_{2}$ \\
\hline $\mathbf{T}_{\mathbf{4}}$ & $50 \% \mathrm{CO}_{2}: 05 \% \mathrm{O}_{2}: 45 \% \mathrm{~N}_{2}$ \\
\hline $\mathbf{T}_{\mathbf{5}}$ & $40 \% \mathrm{CO}_{2}: 05 \% \mathrm{O}_{2}: 55 \% \mathrm{~N}_{2}$ \\
\hline $\mathbf{T}_{\mathbf{6}}$ & $80 \% \mathrm{CO}_{2}: 10 \% \mathrm{O}_{2}: 10 \% \mathrm{~N}_{2}$ \\
\hline $\mathbf{T}_{\mathbf{7}}$ & $70 \% \mathrm{CO}_{2}: 10 \% \mathrm{O}_{2}: 20 \% \mathrm{~N}_{2}$ \\
\hline $\mathbf{T}_{\mathbf{8}}$ & $60 \% \mathrm{CO}_{2}: 10 \% \mathrm{O}_{2}: 30 \% \mathrm{~N}_{2}$ \\
\hline $\mathbf{T}_{\mathbf{9}}$ & $50 \% \mathrm{CO}_{2}: 10 \% \mathrm{O}_{2}: 40 \% \mathrm{~N}_{2}$ \\
\hline $\mathbf{T}_{\mathbf{1 0}}$ & $40 \% \mathrm{CO}_{2}: 10 \% \mathrm{O}_{2}: 50 \% \mathrm{~N}_{2}$ \\
\hline $\mathbf{T}_{\mathbf{1 1}}$ & $50 \% \mathrm{CO}_{2}: 00 \% \mathrm{O}_{2}: 50 \% \mathrm{~N}_{2}$ \\
\hline $\mathbf{T}_{\mathbf{1 2}}$ & Atmospheric air \\
\hline $\mathbf{T}_{\mathbf{1 3}}$ & Vacuum \\
\hline $\mathbf{T}_{\mathbf{1 4}}$ & Storage in cloth bag control \\
\hline $\mathbf{T}_{\mathbf{1 5}}$ & Cold storage \\
\hline
\end{tabular}


Table.1 Effect of modified atmospheric storage conditions on dehydrogenase activity (OD Value) of onion seeds (cv. Arka Kalyan) during storage

\begin{tabular}{|c|c|c|c|}
\hline Treatment & \multicolumn{3}{|c|}{ Months after storage } \\
\hline $\mathrm{CO}_{2}: \mathrm{O}_{2}: \mathrm{N}_{2}$ & 2 & 6 & 12 \\
\hline $\mathrm{T}_{1}: 80 \% \mathrm{CO}_{2}: 05 \% \mathrm{O}_{2}: 15 \% \mathrm{~N}_{2}$ & 0.496 & 0.387 & 0.277 \\
\hline $\mathrm{T}_{2}: 70 \% \mathrm{CO}_{2}: 05 \% \mathrm{O}_{2}: 25 \% \mathrm{~N}_{2}$ & 0.495 & 0.373 & 0.263 \\
\hline $\mathrm{T}_{3}: 60 \% \mathrm{CO}_{2}: 05 \% \mathrm{O}_{2}: 35 \% \mathrm{~N}_{2}$ & 0.494 & 0.363 & 0.253 \\
\hline $\mathrm{T}_{4}: 50 \% \mathrm{CO}_{2}: 05 \% \mathrm{O}_{2}: 45 \% \mathrm{~N}_{2}$ & 0.493 & 0.359 & 0.249 \\
\hline $\mathrm{T}_{5}: 40 \% \mathrm{CO}_{2}: 05 \% \mathrm{O}_{2}: 55 \% \mathrm{~N}_{2}$ & 0.489 & 0.356 & 0.246 \\
\hline $\mathrm{T}_{6}: 80 \% \mathrm{CO}_{2}: 10 \% \mathrm{O}_{2}: 10 \% \mathrm{~N}_{2}$ & 0.491 & 0.358 & 0.248 \\
\hline $\mathrm{T}_{7}: 70 \% \mathrm{CO}_{2}: 10 \% \mathrm{O}_{2}: 20 \% \mathrm{~N}_{2}$ & 0.487 & 0.351 & 0.241 \\
\hline $\mathrm{T}_{8}: 60 \% \mathrm{CO}_{2}: 10 \% \mathrm{O}_{2}: 30 \% \mathrm{~N}_{2}$ & 0.520 & 0.342 & 0.232 \\
\hline $\mathrm{T}_{9}: 50 \% \mathrm{CO}_{2}: 10 \% \mathrm{O}_{2}: 40 \% \mathrm{~N}_{2}$ & 0.483 & 0.338 & 0.228 \\
\hline $\mathrm{T}_{10}: 40 \% \mathrm{CO}_{2}: 10 \% \mathrm{O}_{2}: 50 \% \mathrm{~N}_{2}$ & 0.479 & 0.337 & 0.227 \\
\hline $\mathrm{T}_{11}: 50 \% \mathrm{CO}_{2}: \mathbf{0 0} \% \mathrm{O}_{2}: \mathbf{5 0} \% \mathrm{~N}_{2}$ & 0.494 & 0.369 & 0.259 \\
\hline $\mathbf{T}_{12}$ : Atmospheric air & 0.475 & 0.330 & 0.220 \\
\hline$T_{13}:$ Vacuum & 0.496 & 0.382 & 0.272 \\
\hline$T_{14}:$ Storage in cloth bag (control) & 0.471 & 0.300 & 0.190 \\
\hline$T_{15}:$ Cold storage & 0.497 & 0.390 & 0.280 \\
\hline Mean & 0.490 & 0.353 & 0.243 \\
\hline S.Em. \pm & 0.007 & 0.011 & 0.011 \\
\hline C.D. @ 1\% & NS & 0.031 & 0.031 \\
\hline
\end{tabular}

(Initial dehydrogenase activity: 0.50) 
Table.2 Effect of modified atmospheric storage conditions on $\alpha$-amylase enzyme activity of onion seeds (cv. Arka Kalyan) during storage

\begin{tabular}{|c|c|c|c|}
\hline \multirow{2}{*}{$\begin{array}{cc} & \text { Treatment } \\
\mathrm{CO}_{2}: \mathrm{O}_{2}:\end{array}$} & \multicolumn{3}{|c|}{ Months after storage } \\
\hline & 2 & 6 & 12 \\
\hline $\mathrm{T}_{1}: 80 \% \mathrm{CO}_{2}: 05 \% \mathrm{O}_{2}: 15 \% \mathrm{~N}_{2}$ & 2.50 & 1.89 & 1.28 \\
\hline $\mathrm{T}_{2}: 70 \% \mathrm{CO}_{2}: 05 \% \mathrm{O}_{2}: 25 \% \mathrm{~N}_{2}$ & 2.50 & 1.87 & 1.26 \\
\hline $\mathrm{T}_{3}: 60 \% \mathrm{CO}_{2}: 05 \% \mathrm{O}_{2}: 35 \% \mathrm{~N}_{2}$ & 2.49 & 1.86 & 1.25 \\
\hline $\mathrm{T}_{4}: 50 \% \mathrm{CO}_{2}: 05 \% \mathrm{O}_{2}: 45 \% \mathrm{~N}_{2}$ & 2.49 & 1.86 & 1.25 \\
\hline $\mathrm{T}_{5}: 40 \% \mathrm{CO}_{2}: 05 \% \mathrm{O}_{2}: 55 \% \mathrm{~N}_{2}$ & 2.49 & 1.86 & 1.25 \\
\hline $\mathrm{T}_{6}: 80 \% \mathrm{CO}_{2}: 10 \% \mathrm{O}_{2}: 10 \% \mathrm{~N}_{2}$ & 2.49 & 1.86 & 1.25 \\
\hline $\mathrm{T}_{7}: 70 \% \mathrm{CO}_{2}: 10 \% \mathrm{O}_{2}: 20 \% \mathrm{~N}_{2}$ & 2.49 & 1.85 & 1.24 \\
\hline $\mathrm{T}_{8}: 60 \% \mathrm{CO}_{2}: 10 \% \mathrm{O}_{2}: 30 \% \mathrm{~N}_{2}$ & 2.52 & 1.84 & 1.23 \\
\hline $\mathrm{T}_{9}: 50 \% \mathrm{CO}_{2}: 10 \% \mathrm{O}_{2}: 40 \% \mathrm{~N}_{2}$ & 2.48 & 1.84 & 1.23 \\
\hline $\mathrm{T}_{10}: 40 \% \mathrm{CO}_{2}: 10 \% \mathrm{O}_{2}: 50 \% \mathrm{~N}_{2}$ & 2.48 & 1.84 & 1.23 \\
\hline $\mathrm{T}_{11}: 50 \% \mathrm{CO}_{2}: 00 \% \mathrm{O}_{2}: 50 \% \mathrm{~N}_{2}$ & 2.49 & 1.87 & 1.26 \\
\hline$T_{12}:$ Atmospheric air & 2.48 & 1.83 & 1.22 \\
\hline $\mathbf{T}_{13}:$ Vacuum & 2.50 & 1.88 & 1.27 \\
\hline $\mathbf{T}_{14}:$ Storage in cloth bag (control) & 2.47 & 1.80 & 1.80 \\
\hline$T_{15}:$ Cold storage & 2.50 & 1.89 & 1.28 \\
\hline Mean & 2.49 & 1.85 & 1.29 \\
\hline S.Em. \pm & 0.01 & 0.01 & 0.01 \\
\hline C.D.@1\% & NS & 0.03 & $\mathbf{0 . 0 3}$ \\
\hline
\end{tabular}

(Initial $\alpha$-amylase enzyme activity: 2.56 (u.mol/min/g) 
Table.3 Effect of modified atmospheric storage conditions on catalase enzyme activity of onion seeds (cv. Arka Kalyan) during storage

\begin{tabular}{|c|c|c|c|}
\hline Treatment & \multicolumn{3}{|c|}{ Months after storage } \\
\hline $\mathrm{CO}_{2}: \mathrm{O}_{2}: \mathrm{N}_{2}$ & 2 & 6 & 12 \\
\hline $\mathrm{T}_{1}: 80 \% \mathrm{CO}_{2}: 05 \% \mathrm{O}_{2}: 15 \% \mathrm{~N}_{2}$ & 1.67 & 1.26 & 0.243 \\
\hline $\mathrm{T}_{2}: 70 \% \mathrm{CO}_{2}: 05 \% \mathrm{O}_{2}: 25 \% \mathrm{~N}_{2}$ & 1.67 & 1.26 & 0.229 \\
\hline $\mathrm{T}_{3}: 60 \% \mathrm{CO}_{2}: \mathbf{0 5 \%} \mathrm{O}_{2}: 35 \% \mathrm{~N}_{2}$ & 1.66 & 1.25 & 0.219 \\
\hline $\mathrm{T}_{4}: 50 \% \mathrm{CO}_{2}: 05 \% \mathrm{O}_{2}: 45 \% \mathrm{~N}_{2}$ & 1.66 & 1.25 & 0.215 \\
\hline $\mathrm{T}_{5}: 40 \% \mathrm{CO}_{2}: 05 \% \mathrm{O}_{2}: 55 \% \mathrm{~N}_{2}$ & 1.66 & 1.25 & 0.212 \\
\hline $\mathrm{T}_{6}: 80 \% \mathrm{CO}_{2}: 10 \% \mathrm{O}_{2}: 10 \% \mathrm{~N}_{2}$ & 1.66 & 1.25 & 0.214 \\
\hline $\mathrm{T}_{7}: 70 \% \mathrm{CO}_{2}: 10 \% \mathrm{O}_{2}: 20 \% \mathrm{~N}_{2}$ & 1.66 & 1.24 & 0.207 \\
\hline $\mathrm{T}_{8}: 60 \% \mathrm{CO}_{2}: 10 \% \mathrm{O}_{2}: 30 \% \mathrm{~N}_{2}$ & 1.69 & 1.22 & 0.198 \\
\hline $\mathrm{T}_{9}: 50 \% \mathrm{CO}_{2}: 10 \% \mathrm{O}_{2}: 40 \% \mathrm{~N}_{2}$ & 1.65 & 1.23 & 0.194 \\
\hline $\mathrm{T}_{10}: 40 \% \mathrm{CO}_{2}: 10 \% \mathrm{O}_{2}: 50 \% \mathrm{~N}_{2}$ & 1.65 & 1.23 & 0.193 \\
\hline $\mathrm{T}_{11}: 50 \% \mathrm{CO}_{2}: \mathbf{0 0} \% \mathrm{O}_{2}: \mathbf{5 0} \% \mathrm{~N}_{2}$ & 1.66 & 1.25 & 0.225 \\
\hline$T_{12}:$ Atmospheric air & 1.65 & 1.24 & 0.186 \\
\hline$T_{13}:$ Vacuum & 1.67 & 1.26 & 0.238 \\
\hline$T_{14}:$ Storage in cloth bag (control) & 1.64 & 1.80 & 0.156 \\
\hline$T_{15}:$ Cold storage & 1.67 & 1.28 & 0.246 \\
\hline Mean & 1.66 & 1.28 & 0.209 \\
\hline S.Em. \pm & 0.01 & 0.01 & 0.011 \\
\hline C.D.@1\% & 0.02 & 0.03 & 0.031 \\
\hline
\end{tabular}

(Initial catalase enzyme activity: $1.70(\mathrm{mmol} / \mathrm{min} / \mathrm{g}))$ 
Table.4 Effect of modified atmospheric storage conditions on superoxide dismutase activity (SOD) of onion seeds (cv. Arka Kalyan) during storage

\begin{tabular}{|c|c|c|c|}
\hline \multirow{2}{*}{$\begin{array}{l}\text { Treatment } \\
\text { CO: : } O_{0}:\end{array}$} & \multicolumn{3}{|c|}{ Months after storage } \\
\hline & 2 & 6 & 12 \\
\hline $\begin{array}{l}\mathrm{T}_{1}: 80 \% \mathrm{CO}_{2}: 05 \% \mathrm{O}_{2}: 15 \% \\
\mathrm{~N}_{2}\end{array}$ & 1.89 & 1.16 & 0.897 \\
\hline $\begin{array}{l}\mathrm{T}_{2}: 70 \% \mathrm{CO}_{2}: 05 \% \mathrm{O}_{2}: 25 \% \\
\mathrm{~N}_{2}\end{array}$ & 1.87 & 1.14 & 0.883 \\
\hline $\begin{array}{l}\mathrm{T}_{3}: 60 \% \mathrm{CO}_{2}: 05 \% \mathrm{O}_{2}: 35 \% \\
\mathrm{~N}_{2}: 35\end{array}$ & 1.83 & 1.13 & 0.873 \\
\hline $\begin{array}{l}\mathrm{T}_{4}: 50 \% \mathrm{CO}_{2}: \mathbf{0 5} \% \mathrm{O}_{2}: 45 \% \\
\mathrm{~N}_{2}\end{array}$ & 1.86 & 1.13 & 0.869 \\
\hline $\begin{array}{l}\mathrm{T}_{5}: 40 \% \mathrm{CO}_{2}: 05 \% \mathrm{O}_{2}: 55 \% \\
\mathrm{~N}_{2}\end{array}$ & 1.84 & 1.13 & 0.866 \\
\hline $\begin{array}{l}\mathrm{T}_{6}: 80 \% \mathrm{CO}_{2}: 10 \% \mathrm{O}_{2}: 10 \% \\
\mathrm{~N}_{2}\end{array}$ & 1.82 & 1.13 & 0.868 \\
\hline $\begin{array}{l}\mathbf{T}_{7}: 70 \% \mathrm{CO}_{2}: 10 \% \mathrm{O}_{2}: 20 \% \\
\mathbf{N}_{2}\end{array}$ & 1.85 & 1.12 & 0.861 \\
\hline $\begin{array}{l}\mathrm{T}_{8}: 60 \% \mathrm{CO}_{2}: 10 \% \mathrm{O}_{2}: 30 \% \\
\mathrm{~N}_{2}\end{array}$ & 1.84 & 1.11 & 0.852 \\
\hline $\begin{array}{l}\mathrm{T}_{9}: 50 \% \mathrm{CO}_{2}: 10 \% \mathrm{O}_{2}: 40 \% \\
\mathrm{~N}_{2}\end{array}$ & 1.84 & 1.11 & 0.848 \\
\hline $\begin{array}{l}\mathrm{T}_{10}: 40 \% \mathrm{CO}_{2}: 10 \% \mathrm{O}_{2}: 50 \\
\% \mathrm{~N}_{2}\end{array}$ & 1.84 & 1.11 & 0.847 \\
\hline $\begin{array}{l}\mathrm{T}_{11}: \mathbf{5 0 \%} \mathrm{CO}_{2}: 00 \% \mathrm{O}_{2}: 50 \\
\% \mathrm{~N}_{2}\end{array}$ & 1.91 & 1.14 & 0.879 \\
\hline $\mathbf{T}_{12}$ : Atmospheric air & 1.83 & 0.98 & 0.730 \\
\hline $\mathbf{T}_{13}:$ Vacuum & 1.88 & 1.15 & 0.892 \\
\hline $\begin{array}{l}\mathbf{T}_{14}: \text { Storage in cloth bag } \\
\text { (control) }\end{array}$ & 1.80 & 0.95 & 0.700 \\
\hline $\mathbf{T}_{15}:$ Cold storage & 1.89 & 1.16 & 0.900 \\
\hline Mean & 1.85 & 1.11 & 0.848 \\
\hline S.Em. \pm & 0.02 & 0.01 & 0.011 \\
\hline C.D.@1\% & 0.04 & $\mathbf{0 . 0 3}$ & 0.031 \\
\hline
\end{tabular}

(Initial superoxide dismutase activity: 1.98) 

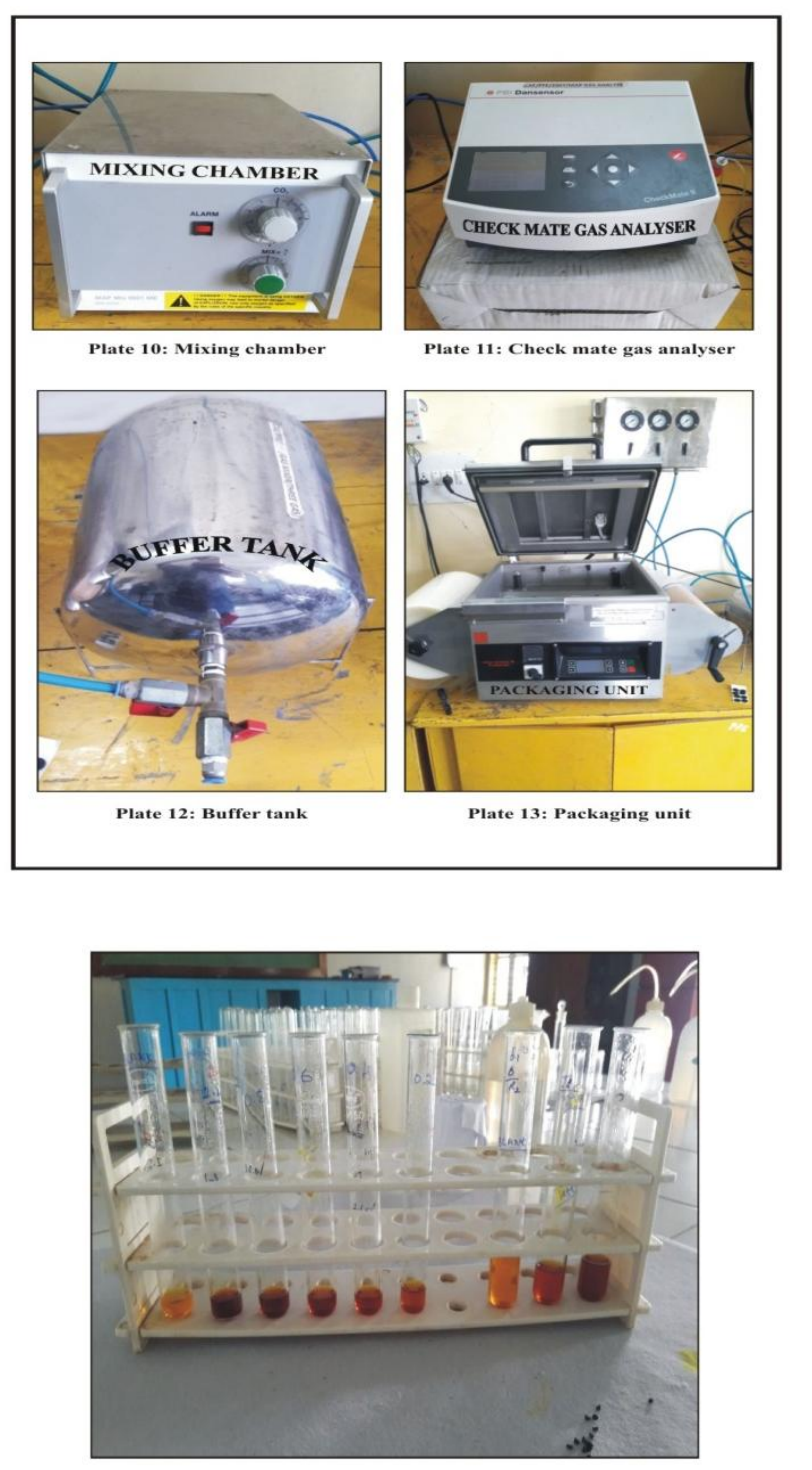

Plate 17: Influence of modified atmospheric packaging on $\alpha$-Amylase activity after 12 months of onion seed storage by DNSA method

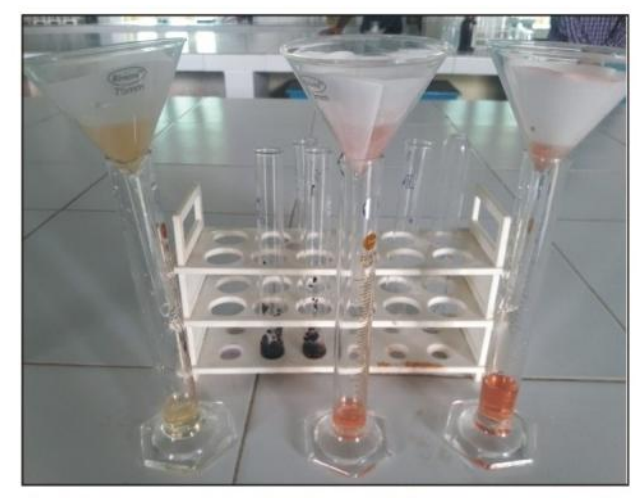

Plate 19: Influence of seed deterioration on dehydrogenase enzyme activity after 12 months of onion seed storage
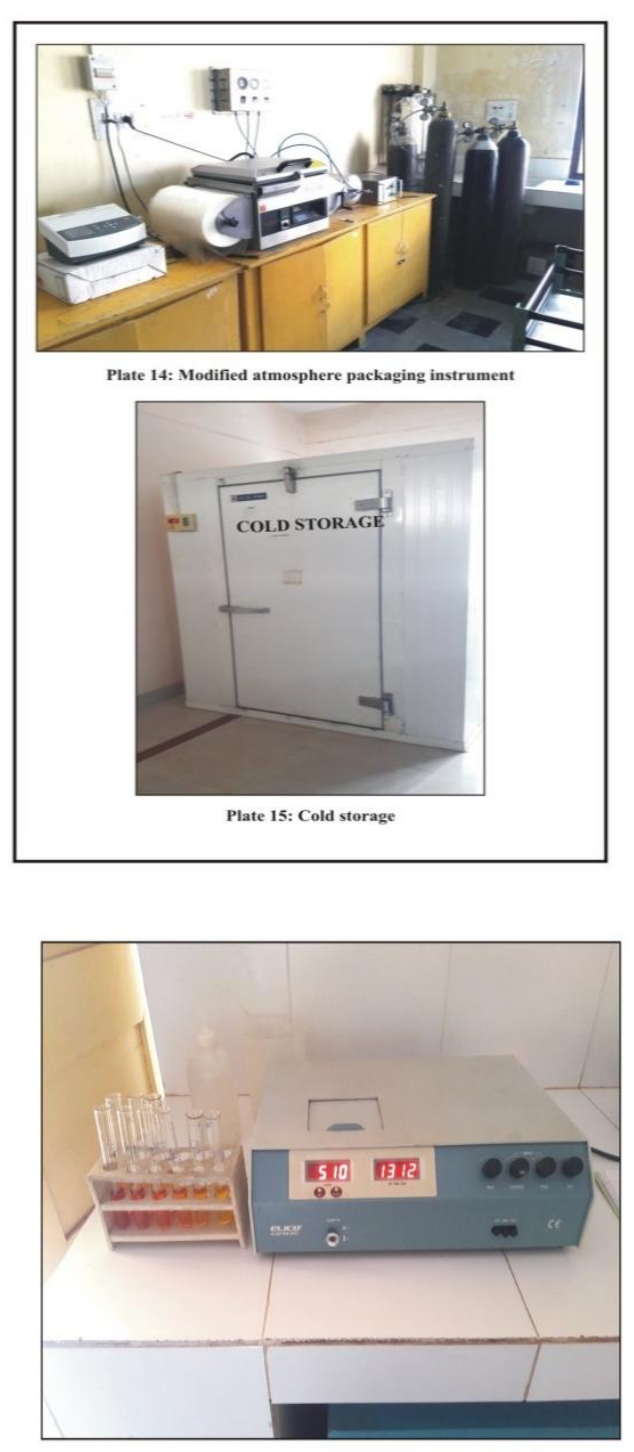

Plate 18: $\alpha$-Amylase activity estimation using Spectrophotometer at $510 \mathrm{~nm}$

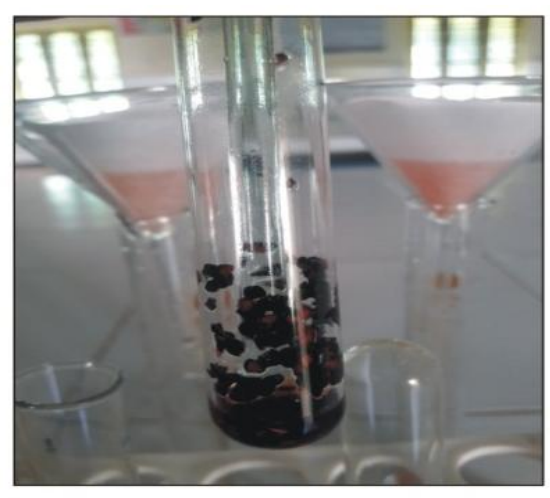

Plate 20: The intensity of red colour was measured using UV-VIS spectrophotometer at $470 \mathrm{~nm}$ 
Summary and conclusions are as follows:

The modified atmospheric storage conditions showed significant effect on vigor and viability of onion seeds. The seeds which stored in cold storage $\left(\mathrm{T}_{15}\right)$ showed better vigor throughout the storage period followed by seeds stored with gaseous combination of $80 \% \mathrm{CO}_{2}: 05 \% \mathrm{O}_{2}: 15 \% \mathrm{~N}_{2}\left(\mathrm{~T}_{1}\right)$ and under vacuum conditions $\left(\mathrm{T}_{13}\right)$ under ambient storage conditions. Among the storage conditions tested, the seeds preserved under cold storage recorded higher field emergence and seedling vigor index with less qualitative loss in comparisons to those seeds stored under ambient condition i.e. in cloth bag throughout the storage period of 12 months.

The study clearly indicated the importance of onion seed storage under cold storage and higher $\mathrm{CO}_{2}$ and lowest $\mathrm{O}_{2}$ for maintenance of seed quality during storage. In case of absence of this facility even seed storage under vacuum is quite satisfactory. The deleterious effect of seeds stored in impervious container and higher oxygen concentration was also revealed during the study.

\section{References}

Bailly, C., Benamar, A., Corbineau, F. and Come, D., 1996, Changes in malondialdehyde content and in superoxide dismutase, catalase and glutathione reductase activities in sunflower seeds as related to deterioration during accelerated ageing. Physiol. Plantarum 97:104-110.

Bailly, C., Benamar, A., Corbineau, F. and Come, D., 2000, Antioxidant systems in sunflower (Helianthus annuus L.) seeds as affected by priming. Seed Sci. Res., 10:35-42.

Bailly, C., R. Bogatek-Leszczynska, D. Côme and F. Corbineau, 2002. Changes in activities of antioxidant enzymes and lipoxygenase during growth of sunflower seedlings from seeds of different vigour. Seed Sci. Res., 12:4755.

Banks, J. and Fields, P., 1995, Physical methods for insect control in storedgrain ecosystems. In: Stored- Grain Ecosystems (Jayas, D. S.; White, N. D. G; Muir W. E, Eds), pp 353-410.Marcel Dekker, Inc., New York.

Benson, E. E., 1990, Free Radical Damage in Stored Plant Germplasm. Int. Board Pl. Gen. Resources, Rome., 3: 296-305.

Bera, A., Sinha, S. N., Ashoka Gaur and Shrivastav, C., 2008 Effect of modified atmospheric storage on seed quality parameters of paddy. Seed Res., 36(1): 56-63.

Bera, A., Sinha, S. N., Singhal, N. C., Pal, R. K. and Srivastava, C., 2004, Studies on carbon dioxide as wheat seed protectant against storage insects and its effect on seed quality stored under ambient conditions. Seed Sci. Technol, 32: 159169.

Gorecki, R. J., Kulka, K. and Puchalski, J., 1996, Biochemical aspects of seed deterioration during storage. In: Proc. of an International Conference on Crop Germplasm Conservation With Special Emphasis On Rye, July 1996, Warsaw, Poland (Eds. T. Gass. W. Podyma, J. Puchalski and S. A Eberhart), Intnat. Plant Genetic Resources Inst., Rome, pp. 50-60.

Hopin, A., S. W. Huang and E. N. Frankel, 1996. Effect of $\alpha$-tocopherol and trolox on the decomposition of methyl linoleate hydroperoxide. Lipids, 31:357365.

Justice, O. L. and Bass, L. N., 1979, Principals and Practices of Seed Storage. Castle House Publication Ltd. London.

Lukasiewicz, M., Jayas, D. S., Muir, W. E. 
and White, N. D. G., 1999, Gas leakage through samples of Wall seams of bolted-metal bins. Canadian Agril. Eng., 41 (1): 25-28.

Narayan Murthy, U. M. and Sun, W. Q., 2000, Protein modification by Amadori and Maillard reactions during seed storage roles of sugar hydrolysis and lipid peroxidation. J. Experi Bot., 51:1221-1228.

Priestley, D. A., 1986, Seed ageing: Implication for seed storage and preservation in the soil. Cornell University Press, Ithaca, New York, p. 304.

Rao, R. G., Singh, P. M. and Rai, M., 2006, Storability of onion seeds and effects of packaging and storage conditions on viability and vigour. Sci. Hort., 110: 1-6.

Rathi, S. S., Shah, N. G., Zambre, S. S., Kalbande, V. H. and Venkatesh K.V.,
2000, Respiration, sorption and germination of seeds stored in controlled atmosphere. Seed Sci. Technol., 28: 341-348.

Rauf, A., 1980, Comparative growth and biochemical on seed development. 6 . Peroxidase and IAA-oidase. $J . P t$. Biochem, 7(2):173-177

Smith, M. T. and Berjak, P., 1995, Deteriorative changes associated with the loss of viability of stored desiccation-tolerant and dessicationsensitive seeds. In: Seed development and germination, Marcel Dekker Inc., New York, pp. 701-746.

Walters, C., 1998, Undertaking the mechanism and kinetics of seed ageing. Seed Sci. Res., 8, 223-244.

Wilson, W. O. and McDonald, H. B., 1986, The lipid peroxidation model of seed ageing. Seed Sci. Technol., 14: 269-300.

\section{How to cite this article:}

Koteshi Lamani, V. K. Deshpande, T. R. Shashidhar and Biradar Patil, N. K. 2020. Enzyme Activity Influenced by Modified Atmospheric Packaging on Onion Seeds (Allium cepa L.) cv. Arka Kalyan. Int.J.Curr.Microbiol.App.Sci. 9(11): 2542-2553.

doi: https://doi.org/10.20546/ijcmas.2020.911.308 